\title{
Mesenchymal stem cells in the treatment of severe COVID-19
}

\author{
Santosh Kesari ${ }^{1 *}$, Gregory C. Kasper ${ }^{2 *}$, Lev Verkh ${ }^{3}$, Terese C. Hammond ${ }^{4}$, Marla L. Matal ${ }^{2}$, Jay W. Hammerling ${ }^{2}$, \\ Nikolai Tankovich ${ }^{3}$, Adrianus P. Lim² ${ }^{2}$ Kevin H. Zhao ${ }^{2}$, Tiffany Juarez ${ }^{1}$, Roberta E. Redfern², Jaya M. Gill', \\ Natsuko Nomura', Audrey Hiemer', Annie Heng ${ }^{1}$ and Jessica Shoemaker ${ }^{2}$
}

\section{To the Editor:}

Researchers have hypothesized the utility of Mesenchymal Stem Cells (MSCs) in treating COVID-19. The severe form of the disease is due to an inflammatory cytokine storm, previously characterized in similar illnesses and possibly responsible for the development of Acute Respiratory Distress Syndrome (ARDS). MSCs have immunomodulatory properties, secreting anti-inflammatory cytokines, inhibiting monocyte differentiation, and regulating the function and proliferation of immune cells [1].

MSCs are used in the treatment of a range of immunemediated inflammatory diseases such as lupus erythematous and graft versus host disease [2, 3]. Moreover, MSCs reduced mortality in $\mathrm{H} 5 \mathrm{~N} 1$ influenza and resulted in improved survival in those with H7N9 influenza strain who developed ARDS [1]. MSCs have activity in the treatment of ARDS, pneumonia, and sepsis, which are among the leading causes of death in COVID-19 cases [4]. Treatment strategies of ARDS is of particular importance in those with COVID-19 due to the potential long-term effects on pulmonary function, as pulmonary fibrosis can continue to develop even after the acute phase of the disease [5]. Despite the potential of MSCs

\footnotetext{
*Correspondence: santoshkesari@gmail.com; Gregory.

KasperMD@promedica.org

${ }^{1}$ Pacific Neuroscience Institute and Providence Saint John's Health

Center, Santa Monica, USA

2 ProMedica Toledo Hospital, 2142 North Cove Blvd, Toledo, $\mathrm{OH} 43606$, USA

Full list of author information is available at the end of the article
}

for treating COVID-19, little patient data has been available thus far.

Here, we report a prospective case series of patients with laboratory confirmed COVID-19 treated with allogenic bone marrow-derived, ischemic tolerant hypoxic MSCs (Stemedica Cell Technology, San Diego, CA USA) at two hospitals in the United States. The data represents nine patients treated under emergency use IND and five treated under an expanded use IND at ProMedica Toledo Hospital (Toledo, OH USA) and Providence Saint John's Health Center (Santa Monica, CA USA). All patients were categorized as severe or critically severe on admission, as previously defined [6]. Patient populations were somewhat dissimilar as shown in Table 1 . Those treated under the expanded use were more severely ill, more often failed other potential COVID-19 treatments, and were infused with MSCs later in their clinical course. All expanded use and five emergency use cases were treated with $50 \times 10^{6}$ cells twice, on average 5 days apart. Four emergency use patients were given a single bolus of $100 \times 10^{6}$ cells, one of whom received approximately $64 \mathrm{M}$ cells. Cells were delivered as an infusion in a central or peripheral line in an upper extremity as a constant rate of $2 \mathrm{M}$ cells/minute. Dose per $\mathrm{kg}$ of body weight varied from $0.42 \times 10^{6}$ cells $/ \mathrm{kg}$ to $1.5 \times 10^{6}$ cells $/ \mathrm{kg}, 0.69 \times 10^{6}$ cells $/ \mathrm{kg}$ on average. Patients were tested for allergic skin reactions with subcutaneous microdose prior to infusion.

Following treatment with MSCs, four of five mechanically ventilated emergency use cases were extubated, exhibiting marked improvement on radiographic examination (Fig. 1). Objective severity category of ARDS as evidenced by $\mathrm{PaO}_{2} / \mathrm{FiO}_{2}$ [7] improved in three 
Table 1 Baseline, treatment, and outcome characteristics of patients treated with Mesenchymal Stem Cells (MSCs) under emergency use and expanded use indications

\begin{tabular}{|c|c|c|c|}
\hline & All patients $(n=14)$ & Emergency use $(n=9)$ & Expanded use $(n=5)$ \\
\hline Median age - years (range) & $58.5(30-84)$ & $64(56-84)$ & $38.0(30-59)$ \\
\hline Female sex - n (\%) & $6(42.9)$ & $4(44.4)$ & $2(40)$ \\
\hline \multicolumn{4}{|l|}{ Comorbid conditions } \\
\hline Cardiovascular disease - $\mathrm{n}(\%)$ & $1(7.1)$ & $1(11.1)$ & $0(0)$ \\
\hline COPD - n (\%) & $4(28.6)$ & $4(44.4)$ & $0(0)$ \\
\hline Hypertension - n (\%) & $7(50)$ & $7(77.8)$ & $0(0)$ \\
\hline Obesity - n (\%) & $8(57.1)$ & $3(33.3)$ & $5(100)$ \\
\hline Other pulmonary disease $-\mathrm{n}(\%)$ & $6(42.9)$ & $6(66.6)$ & $0(0)$ \\
\hline Type II diabetes - n (\%) & $3(21.4)$ & $2(22.2)$ & $1(20)$ \\
\hline \multicolumn{4}{|l|}{ COVID-19 Severity on admission } \\
\hline Severe - n (\%) & $5(35.7)$ & $5(55.6)$ & $0(0)$ \\
\hline Critically severe - n (\%) & $9(64.3)$ & $4(44.4)$ & $5(100)$ \\
\hline $\begin{array}{l}\text { Days of admission prior to treatment with MSCs - median } \\
\text { (range) }\end{array}$ & $10(2-77)$ & $4(2-12)$ & $41(13-77)$ \\
\hline Days between MSC treatments - median (range) ${ }^{\text {a }}$ & $5(2-8)$ & $3(2-3)$ & $7(6-8)$ \\
\hline \multicolumn{4}{|l|}{ Failed or concurrent therapies } \\
\hline Antibiotics & $14(100)$ & $9(100)$ & $5(100)$ \\
\hline Antiviral & $5(35.7)$ & $1(11.1)$ & $4(80)$ \\
\hline Convalescent serum & $6(42.9)$ & $1(11.1)$ & $5(100)$ \\
\hline Hydroxychloroquine & $8(57.1)$ & $5(55.6)$ & $3(60)$ \\
\hline Interleukin-6 inhibitor & $6(42.9)$ & $1(11.1)$ & $5(100)$ \\
\hline Steroids & $10(71.4)$ & $8(88.9)$ & $2(40)$ \\
\hline \multicolumn{4}{|l|}{ Oxygen therapy required } \\
\hline Mechanical ventilation & $10(71.4)$ & $5(55.6)$ & $5(100)$ \\
\hline ECMO & $5(35.7)$ & $0(0)$ & $5(100)$ \\
\hline Pneumonia & $13(92.9)$ & $8(88.9)$ & $5(100)$ \\
\hline Concurrent bacterial pneumonia & $7(50)$ & $2(22.2)$ & $5(100)$ \\
\hline ARDS & $9(64.3)$ & $4(44.4)$ & $5(100)$ \\
\hline LOS post-treatment & $15(2-50)$ & $13(2-50)$ & $17(15-25)$ \\
\hline Total length of stay days ${ }^{b}$ & $31.5(5-98)$ & $17(5-63)$ & $71(45-98)$ \\
\hline \multicolumn{4}{|l|}{ Survival - post treatment with MSCs } \\
\hline 7 days & $13(92.9)$ & $8(88.9)$ & $5(100)$ \\
\hline 14 days & $12(85.7)$ & $7(77.8)$ & $5(100)$ \\
\hline 21 days & $12(85.7)$ & $7(77.8)$ & $5(100)$ \\
\hline 30 days & $9(64.3)$ & $7(77.8)$ & $2(40)$ \\
\hline
\end{tabular}

a 3 of 8 Emergency Use patients were treated with one bolus of $100 \times 10^{6}$ cells

b includes 2 patients admitted at time of writing

(See figure on next page.)

Fig. 1 Chest radiographs of patient prior to and following treatment with Mesenchymal Stem Cells (MSCs). Seventy-nine year old female, with MSC treatment 2 days post-admission; chest radiograph day 0 showing bilateral infiltrates $(\mathbf{A})$ and 12 days post-treatment (B). Sixty-four year old critically severe male, radiograph on day of ventilation and MSC treatment (C). Marked improvement of infiltrates and extubation 8 days following initial MSC infusion (D). 73 year old critically severe male treated with MSCs 12 days after initial admission. Radiograph the day prior to MSC treatment (E) indicates pulmonary infiltrates, which improved by day 9 following MSC infusion (F). Sixty-one year old female categorized as critically severe COVID-19 on admission, treated with MSCs 4 days following admission. Chest $x$-rays one day prior to MSC infusions indicates severe pulmonary infection $(\mathbf{G})$ which substantially improved by day 11 post-treatment $(\mathbf{H})$. Eighty-four year old male treated with MSCs 11 days after admission. Pre-treatment radiograph (I) on day 11 shows mild worsening of patchy airspace opacities bilaterally. There was slow improvement over time and infiltrates reduced on day 22 following MSC treatment (J). 30 year old female treated with MSCs 57 days after admission. Pre-treatment radiograph (K) on day 56 shows stable severe diffuse multifocal pulmonary opacities and focal lucencies within both upper lung zones which may represent loculated pleural air or parenchymal cavitation. Infiltrates reduced on day 4 following MSC treatment (L) 

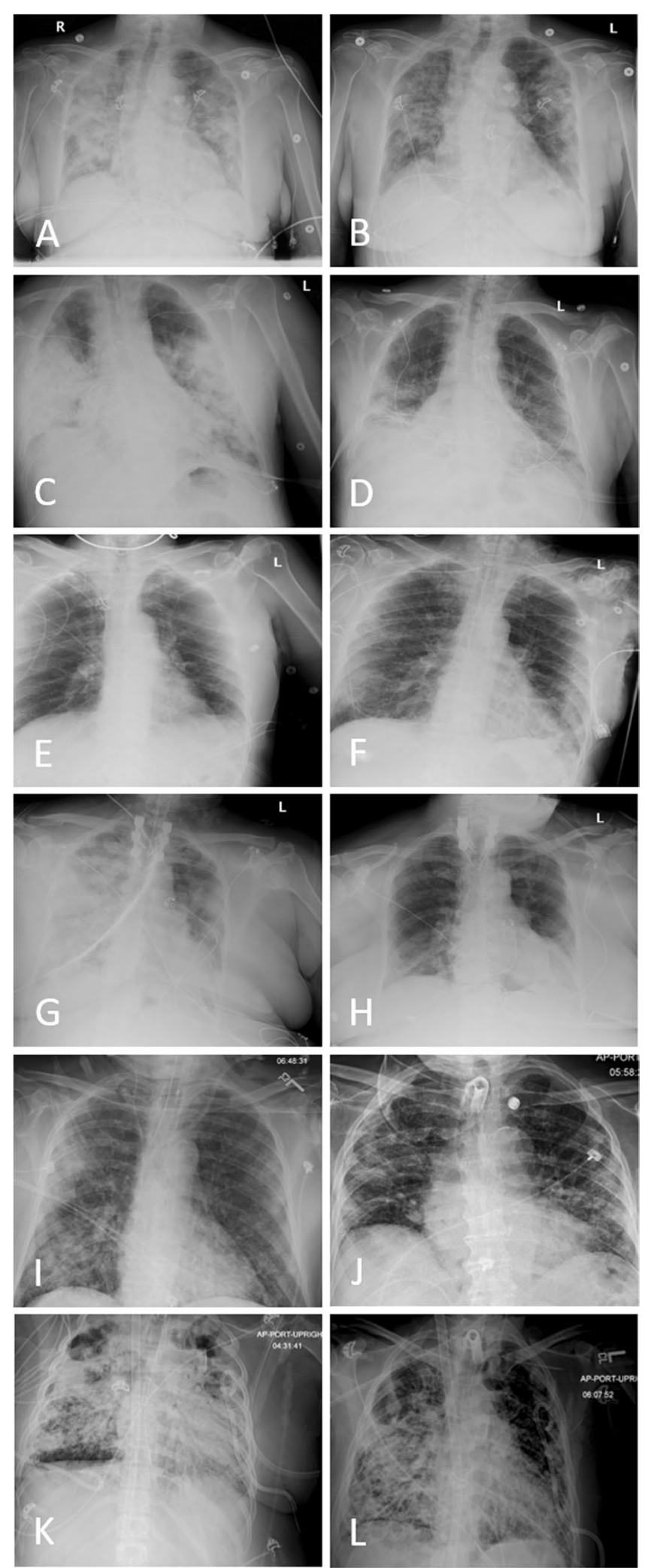

Fig. 1 (See legend on previous page.) 
emergency use cases and one expanded use case within 21 days post-treatment. Laboratory results suggest that inflammatory markers were modulated by treatment with MSCs however were not significant in this small sample size. Overall survival was favorable; $92.9 \%$ of all cases survived 7 days post-treatment and $64.3 \%$ were alive at 30 days. Cause of death for both patients treated under the emergency use IND was cardiopulmonary failure; COVID-19-related ARDS was cited as the cause in all three patients who expired in the expanded use group. Importantly, no adverse events attributable to the MSC infusion were observed, suggesting the treatment is safe in this disease. At the time of writing, seven patients have been discharged. Five of the seven patients discharged from the hospital reported that their subjective overall function had returned to, or nearly to, baseline on follow up. One remains admitted to a long-term care facility; two others continue to be treated in the ICU.

While this was not a clinical trial designed and powered for comparisons, our data suggest that those who received MSCs earlier in their clinical course of disease may have appreciated more benefit; it is possible that earlier treatment may help prevent the cytokine storm, rather than attempting to reverse it. While our data must be interpreted with caution given the limitations, it may provide some guidance for the design of future trials using MSCs to battle COVID-19.

\section{Acknowledgements}

Not applicable

\begin{abstract}
Authors' contributions
SK, NT and LV contributed to the conception and the design of the work GCK, TCH, MLM, KHZ, APL, JWH, and TJ contributed to the design. APL, KHZ, MLM, JWH, TJ, JMG, RER, NN, AH, AH, JS contributed to data acquisition. SK, NT, LV, GCK, TJ and RER contributed to the analysis and SK, NT, LV, GCK, MLM, $\mathrm{JWH}, \mathrm{APL}, \mathrm{TCH}$ contributed to the interpretation of the data. RER drafted the manuscript. GCK, TCH, SK, LV, NT, JWH, and TJ critically revised the manuscript. All authors gave final approval and agree to be accountable for all aspects of work ensuring integrity and accuracy. All authors read and approved the final manuscript.
\end{abstract}

\section{Funding}

We thank Will and Cary Singleton for support of the Pacific Neuroscience Institute Stem Cell Program and Stemedica for providing cells.

\section{Availability of data and materials}

All data generated or analyzed during this study are included in this published article.

\section{Declarations}

\section{Ethics approval and consent to participate}

All patients consented to emergency use of this investigational treatment. The local Institutional Review Board approved the study; a waiver of authorization was approved to retrospectively collect data.

\section{Consent for publication}

Not applicable.

\section{Competing interests}

Lev Verkh and Nikolai Tankovich are employees of Stemedica Cell Technologies, Inc., which provided the stem cells used in this report.

\section{Author details}

${ }^{1}$ Pacific Neuroscience Institute and Providence Saint John's Health Center, Santa Monica, USA. ${ }^{2}$ ProMedica Toledo Hospital, 2142 North Cove Blvd, Toledo, $\mathrm{OH}$ 43606, USA. ${ }^{3}$ Stemedica Cell Technologies, Inc., San Diego, USA. ${ }^{4}$ Providence Saint John's Health Center, Santa Monica, USA. ${ }^{5}$ Pacific Neuroscience Institute, Santa Monica, USA.

Received: 1 March 2021 Accepted: 13 July 2021

Published online: 09 August 2021

\section{References}

1. Bamba C, Singh SP, Choudhury S. Can mesenchymal stem cell therapy be the interim management of COVID-19? Drug Discov Ther. 2020;14:139-42.

2. Tyndall A, van Laar JM. Stem cell transplantation and mesenchymal cells to treat autoimmune diseases. Presse Med. 2016:45(6 Pt 2):e159-69.

3. Lin F, Ichim TE, Pingle $\mathrm{S}$, et al. Mesenchymal stem cells as living antiinflammatory therapy for COVID-19 related acute respiratory distress syndrome. World J Stem Cells. 2020;12(10):1067-79.

4. Moll G, Drzeniek N, Kamhieh-Milz J, et al. MSC therapies for COVID-19: importance of patient coagulopathy, thromboprophylaxis, cell product quality and mode of delivery for treatment safety and efficacy. Front Immunol. 2020:11:1091.

5. Taghavi-Farahabadi M, Mahmoudi M, Soudi S, Hashemi SM. Hypothesis for the management and treatment of the COVID-19-induced acute respiratory distress syndrome and lung injury using mesenchymal stem cell-derived exosomes. Med Hypotheses. 2020;144:109865.

6. Leng Z, Zhu R, Hou W, et al. Transplantation of ACE2(-) mesenchymal stem cells improves the outcome of patients with COVID-19 pneumonia. Aging Dis. 2020;11(2):216-28.

7. Force ADT, Ranieri VM, Rubenfeld GD, et al. Acute respiratory distress syndrome: the Berlin Definition. JAMA. 2012;307(23):2526-33.

\section{Publisher's Note}

Springer Nature remains neutral with regard to jurisdictional claims in published maps and institutional affiliations.

$$
\begin{aligned}
& \text { Ready to submit your research? Choose BMC and benefit from: } \\
& \text { - fast, convenient online submission } \\
& \text { - thorough peer review by experienced researchers in your field } \\
& \text { - rapid publication on acceptance } \\
& \text { - support for research data, including large and complex data types } \\
& \text { - gold Open Access which fosters wider collaboration and increased citations } \\
& \text { - maximum visibility for your research: over 100M website views per year } \\
& \text { At BMC, research is always in progress. } \\
& \text { Learn more biomedcentral.com/submissions }
\end{aligned}
$$

